\title{
Expression of the nifA gene of Herbaspirillum seropedicae: role of the NtrC and NifA binding sites and of the $-24 /-12$ promoter element
}

\author{
E. M. Souza, ${ }^{1} \dagger$ F. O. Pedrosa, ${ }^{2}$ L. U. Rigo, ${ }^{2}$ H. B. Machado ${ }^{3}$ \\ and M. G. Yates ${ }^{1} \dagger$ \\ Author for correspondence: E. M. Souza. Tel: +55 41266 2042. Fax: + 55413664398. \\ e-mail:souzaem@bio.ufpr.br
}

1 BBSRC, IPSR - Nitrogen Fixation Laboratory, University of Norwich, Norwich, UK

2 Departamento de Bioquímica - UFPR, C. Postal 19046, 81531-970, Curitiba, PR, Brazil

3 Departamento de Farmacologia, UFPR, 81531-990, Curitiba, PR, Brazil

\begin{abstract}
The nifA promoter of Herbaspirillum seropedicae contains potential NtrC, NifA and IHF binding sites together with a $-12 /-24 \sigma^{\mathrm{N}}$-dependent promoter. This region has now been investigated by deletion mutagenesis for the effect of NtrC and NifA on the expression of a nifA:: lacZ fusion. A 5' end to the RNA was identified at position 641,12 bp downstream from the $-12 /-24$ promoter. Footprinting experiments showed that the $G$ residues at positions -26 and $\mathbf{- 9}$ are hypermethylated, and that the region from -10 to +10 is partially melted under nitrogen-fixing conditions, confirming that this is the active nifA promoter. In $H$. seropedicae nifA expression from the $\sigma^{N}$-dependent promoter is repressed by fixed nitrogen but not by oxygen and is probably activated by the NtrC protein. NifA protein is apparently not essential for nifA expression but it can still bind the NifA upstream activating sequence.
\end{abstract}

Keywords: Herbaspirillum seropedicae, nitrogen fixation, nifA gene

\section{INTRODUCTION}

Herbaspirillum seropedicae is an endophytic nitrogenfixing bacterium found associated with several grasses, which fixes nitrogen under micro-oxic conditions and in the absence of a fixed nitrogen source (Baldani et al., 1986; Boddey et al., 1995). Initially classified as an Azospirillum species, it is now placed in the rRNA superfamily III or $\beta$-subdivision of the Proteobacteria (Young, 1992). This subdivision, which is the least studied genetically of nitrogen-fixing families, includes species of Rhodocyclus, Alcaligenes, Derxia and Azoarcus.

The NifA protein is a specific activator of the expression of nif gene promoters by interaction with $\sigma^{\mathrm{N}}\left(\sigma^{54}\right.$, RpoN)-containing RNA polymerase, which recognizes promoters with the dinucleotides GG and GC conserved at positions $-25 /-24$ and $-12 /-13$, respectively (Dixon, 1988). The NifA protein binds to a specific upstream activating sequence (UAS) and interacts with the $\sigma^{\mathrm{N}}$-containing RNA polymerase bound to the promoter to induce open complex formation (Morett \&

†Present address: Departamento de Bioquímica - UFPR, C. Postal 19046, 81531-970, Curitiba, PR, Brazil.

Abbreviations: DMS, dimethysulphate; UAS, upstream activating sequence.
Buck, 1989). This mechanism is common to all nitrogenfixing proteobacteria to date.

The regulation of nif $A$ expression, on the other hand, differs, depending on the organism. In Klebsiella pneumoniae, the phosphorylated NtrC protein activates nif $A$ gene expression under nitrogen limitation. NtrC is phosphorylated by NtrB, whose activity is controlled by the cellular nitrogen status via the proteins $G \ln B$ and GlnD (see Merrick \& Edwards, 1995). In Rhizobium meliloti (now Sinorhizobium meliloti), nifA and fixK expression (Batut et al., 1989; David et al., 1988) is activated by the Fix J protein, which is inactivated under high oxygen by the FixL protein, while the FixK protein negatively regulates nifA expression. The NifA protein also activates its own expression (Batut et al., 1989). In Azorhizobium caulinodans full expression of the nif $A$ promoter occurs only under micro-oxic and low fixed nitrogen conditions (Loroch et al., 1995) when FixJ activates fixK expression and FixK, in turn, activates nifA expression, in apparent contrast to the situation in $S$. meliloti. A NifA UAS is also present in the $A$. caulinodans nifA promoter and is possibly involved in negative auto-regulation (Nees et al., 1988; Stigter et al., 1992). Finally, the NrfA protein has also been implicated in translational nifA regulation (Kaminski \& Elmerich, 1998). The nifA gene of Bradyrhizobium japonicum is in the operon fixRnifA, which is positively regulated by an 
oxygen-sensitive NifA protein (Fischer \& Hennecke, 1987). In this organism, however, nifA is expressed primarily from another promoter activated by the RegR protein (Bauer et al., 1998). The nifA gene expression in Azospirillum brasilense is not tightly regulated by either fixed nitrogen or oxygen, although a significant decrease of expression occurs in the presence of high levels of both ammonia and oxygen together (Liang et al., 1991). Both ammonia and oxygen, on the other hand, apparently regulate NifA activity since there is no activation of nifH under such conditions. The PII protein probably participates in the regulation of NifA protein activity since a $g \ln B$ null mutant of $A$. brasilense is $\mathrm{Nif}^{-}$ even when the nif $A$ gene is expressed constitutively (de Zamaroczy et al., 1993; Arsene et al., 1996).

The promoter region of the nifA gene of $H$. seropedicae was found to contain sequences homologous to a $-24 /-12$ type promoter, together with NifA and NtrC binding sites (Souza et al., 1991a), suggesting participation of these proteins in the expression of the nifA gene. The activity of the NifA protein from $H$. seropedicae is controlled by ammonium ions and oxygen (Souza et al., 1999). nif gene expression in H. seropedicae apparently requires a functional $g \ln B$-like gene (Benelli et al., 1997).

Here we report the identification of a major transcriptional-start site of the nifA gene of $H$. seropedicae under nitrogen-fixing conditions, verification of a $-24 /-12$ transcriptionally active promoter and an analysis of the roles of NifA and NtrC proteins in the activation of nifA expression.

\section{METHODS}

Strains and plasmids. The bacterial strains and plasmids used are listed in Table 1. The Herbaspirillum seropedicae strain SmR1 is a spontaneous streptomycin-resistant $\left(100 \mu \mathrm{g} \mathrm{ml}^{-1}\right)$ mutant isolated from H. seropedicae Z78 (Baldani et al., 1986).

Media and growth conditions. H. seropedicae was grown in JNFbP medium (Baldani et al., 1986) supplemented with $20 \mathrm{mM} \mathrm{NH}_{4} \mathrm{Cl}$ (JNFbPN). Escherichia coli was grown in LB or $2 \times$ YT medium (Sambrook et al., 1989). The minimal medium for E. coli was NFDM (Dixon et al., 1977) supplemented with $20 \mathrm{mM} \mathrm{NH}_{4} \mathrm{Cl}$. The concentrations of antibiotics used were as follows: carbenicillin, $200 \mu \mathrm{g} \mathrm{ml}^{-1}$; tetracycline, $10 \mu \mathrm{g} \mathrm{ml}^{-1}$; streptomycin, $20 \mu \mathrm{g} \mathrm{ml}^{-1}$ (E. coli) or $100 \mu \mathrm{g} \mathrm{ml}^{-1}(H$. seropedicae); kanamycin, $50 \mu \mathrm{g} \mathrm{ml}^{-1}$ (E. coli) or $250 \mu \mathrm{g} \mathrm{m} l^{-1}$ (H. seropedicae); chloramphenicol, $30 \mu \mathrm{g} \mathrm{ml}^{-1}$ (E. coli) or $150 \mu \mathrm{g} \mathrm{ml}^{-1}$ (H. seropedicae); nalidixic acid, $20 \mu \mathrm{g} \mathrm{ml}^{-1}$.

Conjugation. Plasmids were introduced into $H$. seropedicae by triparental matings (Pedrosa \& Yates, 1984), using pRK2013 as the helper plasmid.

Construction of nifA mutants. A $6.5 \mathrm{~kb}$ BamHI-HindIII fragment from pEMS101 containing H. seropedicae DNA was cloned in pSUP202, producing pEMS108. This plasmid was mutagenized using the Tn5-lacZ construct Tn5-B21 (Simon et al., 1989) to obtain a transposon insertion approximately $300 \mathrm{bp}$ downstream from the nifA translation start. The orientation of $l a c Z$ in this plasmid, named pEMS109, was the same as that of the nifA gene. A $2 \mathrm{~kb}$ SalI fragment from pEMS101, containing part of the nif $A$ gene, was also cloned into pSUP202 and the kanamycin-resistance cassette from pKIXX was inserted into the BglII site in the nif $A$ gene to give the plasmid pEMS109.1. H. seropedicae nifA mutants were then obtained by introducing these mutated plasmids pEMS109 and pEMS109.1 into H. seropedicae by conjugation, producing strains SmR2532 and SmR54, respectively. Recombinant colonies resistant to the transposon or cassette markers were screened for a combination of the vector marker (chloramphenicol sensitivity), $\beta$-galactosidase and nitrogenase activities. Only $1-5 \%$ of the recombinant colonies were products of a double crossover, as judged by the above parameters. The transposon or cassette insertion in the nifA gene was confirmed by chromosomal DNA hybridization following restriction and electrophoresis (not shown).

Construction of nifA::lacZ fusions. The $6.5 \mathrm{~kb}$ Pst $\mathrm{I}-\mathrm{X}$ ol fragment from plasmid pEMS109 (nifA::Tn5-B21), containing the whole nifA promoter region and the lac $Z$ gene, was cloned into EcoRI/PstI-digested pBR322, yielding pEMS111. pEMS114 was constructed by cutting pEMS111 with DraI and religating. This construction contains the NifA UAS and the $-24 /-12$ promoter sequence.

Another set of nif $A:$ :lac $Z$ fusions was constructed using the IncP fusion vectors pPW452 and pMP220 (Fig. 1a, b). A $1.7 \mathrm{~kb}$ EcoRI fragment containing part of the N-terminal of the nif $A$ gene and the whole promoter region was cloned into the transcriptional fusion vector pPW452, yielding the plasmid pEMS120, in which lacZ expression was under control of the nifA promoter. Deletions in the promoter region were prepared by cloning the $0.4 \mathrm{~kb} E c o \mathrm{RI}-N$ siI, the $0.5 \mathrm{~kb}$ EcoRI-DraI and the $0.5 \mathrm{~kb}$ EcoRI-SspI subfragments from the $1.7 \mathrm{~kb}$ EcoRI fragment into pPW452 producing pEMS121, pEMS122 and pEMS123, and the $0.7 \mathrm{~kb}$ EcoRI-PmlI fragment into pMP220 yielding pEMS124. The $1.3 \mathrm{~kb}$ EcoRI-NsiI and $1 \cdot 2 \mathrm{~kb}$ EcoRI-DraI fragments were cloned into pMP220 to produce pEMS125 and pEMS126, and the $1.0 \mathrm{~kb}$ EcoRI-PmlI fragment into pPW452 to produce pEMS127. The EcoRI-DraI and EcoRI-SspI fragments were cloned first into pTZ18 digested with EcoRI/SmaI and then transferred as EcoRI-PstI fragments to pMP220 and pPW452 digested with EcoRI/PstI (Table 1). The EcoRI-PmlI fragments were also cloned into pTZ18 digested with EcoRI/SmaI and cloned as EcoRIBamHI fragments into pPW452 and pMP220 digested with EcoRI/BglII. The EcoRI-NsiI fragments were cloned in pMP220 and pPW452 digested with EcoRI/PstI (see Table 1).

$\boldsymbol{\beta}$-Galactosidase activity. Studies of the expression of the $H$. seropedicae nifA gene in E. coli were as follows: NFDM (2 ml) in a bijou bottle containing glutamine $\left(100 \mu \mathrm{g} \mathrm{ml} \mathrm{m}^{-1}\right)$ plus antibiotics was inoculated with $50 \mu \mathrm{l}$ of an overnight culture in $2 \times \mathrm{YT}$ in air and shaken for $18-20 \mathrm{~h}$ at $30^{\circ} \mathrm{C}$. $\mathrm{NH}_{4} \mathrm{Cl}(20$ $\mathrm{mM}$ ) was added when necessary.

Derepression experiments in $H$. seropedicae were conducted with overnight-grown cultures. The cells were collected by centrifugation and resuspended in either fresh JNFbP or JNFbPN to an $\mathrm{OD}_{600}$ of $0 \cdot 2$. The cell suspension $(2 \mathrm{ml})$ was transferred to $25 \mathrm{ml}$ conical flasks containing either oxygen $\left(1.5 \%\right.$ in $\left.\mathrm{N}_{2}\right)$ or air and shaken for $5-6 \mathrm{~h}$ at $30^{\circ} \mathrm{C}$. The $\beta$ galactosidase activity was then determined, using ONPG as the substrate (Miller, 1972).

RNA 5' end mapping. RNA was purified from $H$. seropedicae grown under nitrogen-fixing conditions (Krol et al., 1982). The single-stranded probe used for S1 mapping was obtained by asymmetric PCR using 2 pmol primer 1 (5'-ATGCGCTGCCTGAGAGCGCT-3') end-labelled with $\left[\gamma^{32} \mathrm{P}\right]$ ATP (Amersham). Conditions of hybridization and digestion were as in Sambrook et al. (1989). 
Table 1. Strains and plasmids

\begin{tabular}{|c|c|c|}
\hline Strain/plasmid & Genotype/phenotype & Reference/source \\
\hline \multicolumn{3}{|l|}{$\begin{array}{l}\text { H. seropedicae } \\
\text { strains }\end{array}$} \\
\hline SmR1 & $\mathrm{Sm}^{\mathrm{R}}, \mathrm{Nif}^{+}$ & This work \\
\hline SmR2532 & $\mathrm{Sm}^{\mathrm{R}}$, nif $A:: \operatorname{Tn} 5-\mathrm{B} 21$ (nifA::lacZ, $\mathrm{Tc}^{\mathrm{R}}$ ) & This work \\
\hline SmR54 & $\mathrm{Sm}^{\mathrm{R}}$, nif $A:: \mathrm{Km}\left(\mathrm{Km}^{\mathrm{R}}\right)$ & This work \\
\hline \multicolumn{3}{|l|}{ E. coli strains } \\
\hline ET8894 & $\Delta(r h a-n t r C) 1703::$ Mucts 62 & MacNeil (1981) \\
\hline ET8045 & rpoN208:: Tn10 & MacNeil (1981) \\
\hline $\begin{array}{l}\text { Plasmids } \\
\text { pRK2013 }\end{array}$ & $\mathrm{Km}^{\mathrm{R}}$, tra & $\begin{array}{l}\text { Figurski \& Helinski } \\
\text { (1979) }\end{array}$ \\
\hline pEMS101 & $\mathrm{Km}^{\mathrm{R}}$, HsnifA in $\mathrm{pVK} 102$ & Souza et al. (1991a) \\
\hline pEMS107 & $\mathrm{Tc}^{\mathrm{R}}$, HsnifA in $\mathrm{pVK} 102$ & Souza et al. (1991a) \\
\hline pEMS108 & $\mathrm{Cm}^{\mathrm{R}} \mathrm{Cb}^{\mathrm{R}}$, HsnifA in pSUP202 & This work \\
\hline pEMS109 & $\mathrm{Tc}^{\mathrm{R}} \mathrm{Cm}^{\mathrm{R}} \mathrm{Cb}^{\mathrm{R}}$, HsnifA:: Tn5-B21 in pSUP202 & This work \\
\hline pEMS109.1 & $\mathrm{Km}^{\mathrm{R}} \mathrm{Cm}^{\mathrm{R}} \mathrm{Cb}^{\mathrm{R}}$, HsnifA:: Km in pSUP202 & This work \\
\hline pEMS111 & $\mathrm{Tc}^{\mathrm{R}}$, nif $A:$ : lacZ in $\mathrm{pBR} 322$ & This work \\
\hline pEMS112 & $\mathrm{Tc}^{\mathrm{R}}$, nif $A::$ lac Z IncP & This work \\
\hline pEMS114 & $\mathrm{Tc}^{\mathrm{R}}$, nifA:: lac $Z$ in $\mathrm{pBR} 322$ & This work \\
\hline pEMS135 & $\mathrm{Tc}^{\mathrm{R}}$, MaeI fragment in pLAFR3.18 and HsnifA expressed from lac promoter & This work \\
\hline pEMS120 & $\mathrm{Tc}^{\mathrm{R}}, 1.7 \mathrm{~kb}$ EcoRI fragment containing whole HsnifA promoter in pPW452 & This work \\
\hline pEMS121 & $\mathrm{Tc}^{\mathrm{R}}, 0 \cdot 4 \mathrm{~kb}$ EcoRI-Nsil fragment containing part of HsnifA promoter in pPW452 & This work \\
\hline pEMS122 & $\mathrm{Tc}^{\mathrm{R}}, 0.5 \mathrm{~kb}$ EcoRI-DraI fragment containing part of HsnifA promoter in pPW452 & This work \\
\hline pEMS123 & $\mathrm{Tc}^{\mathrm{R}}, 0.5 \mathrm{~kb}$ EcoRI-SspI fragment containing part of HsnifA promoter in pPW452 & This work \\
\hline pEMS124 & $\mathrm{Tc}^{\mathrm{R}}, 0.7 \mathrm{~kb}$ EcoRI-PmlI fragment containing part of HsnifA promoter in pMP220 & This work \\
\hline pEMS125 & $\mathrm{Tc}^{\mathrm{R}}, 1 \cdot 3 \mathrm{~kb}$ EcoRI-NsiI fragment containing part of HsnifA promoter in pMP220 & This work \\
\hline pEMS126 & $\mathrm{Tc}^{\mathrm{R}}, 1 \cdot 2 \mathrm{~kb}$ EcoRI-DraI fragment containing part of HsnifA promoter in pMP220 & This work \\
\hline pEMS127 & $\mathrm{Tc}^{\mathrm{R}}, 1 \cdot 0 \mathrm{~kb}$ EcoRI-PmlI fragment containing part of HsnifA promoter in pPW452 & This work \\
\hline pSUP202 & $\mathrm{Tc}^{\mathrm{R}} \mathrm{Cb}^{\mathrm{R}} \mathrm{Cm}^{\mathrm{R}}, \mathrm{Mob}^{+}$ & Simon et al. (1983) \\
\hline pBR322 & $\mathrm{Tc}^{\mathrm{R}} \mathrm{Cb}^{\mathrm{R}}$ & Sambrook et al. (1989) \\
\hline pKIXX & $\mathrm{Cb}^{\mathrm{R}} \mathrm{Km}^{\mathrm{R}}$ & Pharmacia \\
\hline pVK102 & $\mathrm{Tc}^{\mathrm{R}} \mathrm{Km}^{\mathrm{R}}, \mathrm{Mob}^{+}$ & Knauf \& Nester (1982) \\
\hline pTZ18 & $\mathrm{Cb}^{\mathrm{R}}$ & Pharmacia \\
\hline pCK1 & $\mathrm{Sm}^{\mathrm{R}}$, IncQ Kpnif $A^{\mathrm{C}}$ & $\begin{array}{l}\text { Kennedy \& Robson } \\
\text { (1983) }\end{array}$ \\
\hline $\mathrm{pMC71A}$ & $\mathrm{Cm}^{\mathrm{R}}, K p n i f A^{\mathrm{C}}$ & $\begin{array}{l}\text { Buchanan-Wollaston et } \\
\text { al. (1981) }\end{array}$ \\
\hline pNH11 & $\mathrm{Cb}^{\mathrm{R}}$, KpnifA expressed from tac promoter & Austin et al. (1990) \\
\hline pMM14 & $\mathrm{Km}^{\mathrm{R}}, \mathrm{KpntrC}^{\mathrm{C}}$ & Merrick (1983) \\
\hline pMP220 & lacZ fusion vector, IncP & Spaniak et al. (1987) \\
\hline pPW452 & As pMP220, but with inverted cloning nest & P. Woodley* \\
\hline
\end{tabular}

* Nitrogen Fixation Laboratory, University of Norwich, Norwich, UK.

Recombinant DNA techniques. All DNA manipulations including cloning, end-labelling and transformations were performed by current techniques (Sambrook et al., 1989).

In vivo footprinting. For dimethylsulphate (DMS) footprinting, an overnight culture of E. coli ET8894 carrying the relevant plasmids was diluted to an $\mathrm{OD}_{600}$ of $0 \cdot 1$ in $2 \times \mathrm{YT}$ and shaken at $30{ }^{\circ} \mathrm{C}$ until the $\mathrm{OD}_{600}$ was $0 \cdot 5-0 \cdot 7$. The culture was treated with DMS $(0.05 \%, \mathrm{v} / \mathrm{v})$ for $2 \mathrm{~min}$; the cells were then collected by centrifugation and washed in Tris/ $\mathrm{HCl}(50$ $\mathrm{mM}, \mathrm{pH} 8.0)$, EDTA $(10 \mathrm{mM})$ solution. The methylated plasmids were purified by alkaline lysis (Sambrook et al., 1989).
For in vivo DMS footprinting in $H$. seropedicae, an overnight culture of a strain carrying pEMS120 (nifA: :lacZ fusion) was centrifuged, diluted to an $\mathrm{OD}_{600}$ of $1 \cdot 1$ in $20 \mathrm{ml} \mathrm{JNFbP}$ or $\mathrm{JNFbPN}$ in a $65 \mathrm{ml}$ bottle and incubated in a rotary shaker at 120 r.p.m. for 5 h. The culture was treated with freshly prepared DMS $(0.05 \%, \mathrm{v} / \mathrm{v}$, final concn) for $2 \mathrm{~min}$ and plasmid purification was done as above. When used, rifampicin $\left(100 \mu \mathrm{g} \mathrm{ml}^{-1}\right)$ was added $7 \mathrm{~min}$ before the addition of DMS. To cleave the DNA at the methylated G residues, the plasmid DNA isolated after DMS treatment was dissolved in $30 \mu \mathrm{l} 1 \mathrm{M}$ piperidine, incubated at $90{ }^{\circ} \mathrm{C}$ for $30 \mathrm{~min}$ and submitted to 3 cycles of lyophilization followed by dissolution 


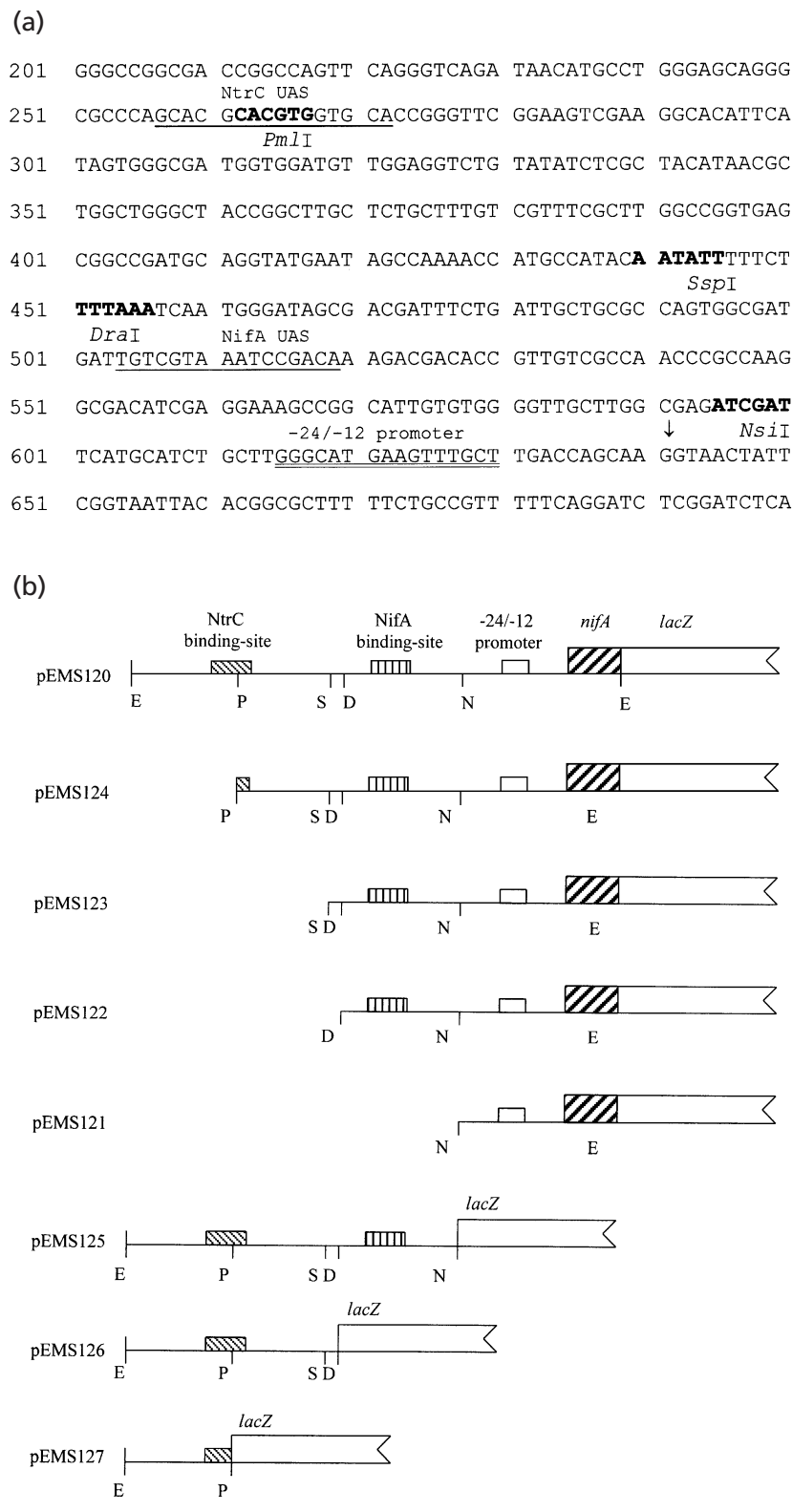

Fig. 1. Construction of nifA::lacZ fusions. (a) Nucleotide sequence of the promoter region of $H$. seropedicae nifA. The NtrC and NifA UASs are underlined, the $-24 /-12$ promoter element is double underlined and the arrow indicates the RNA start site. (b) Scheme of the nifA::lacZ fusions. Restriction enzymes are: E, EcoRI; P, Pmll; S, Sspl; D, Dral; N, Nsil.

in $20 \mu \mathrm{l}$ water. The cleaved DNA was used as the template for primer extension with Taq DNA polymerase (Sasse-Dwight \& Gralla, 1991).

For in vivo $\mathrm{KMnO}_{4}$ footprinting, an overnight culture of a $\mathrm{H}$. seropedicae strain carrying the nifA:lacZ fusion was derepressed as above. Freshly prepared potassium permanganate $(15 \mathrm{mM}$, final concn) was added and the cultures incubated for $5 \mathrm{~min}$. When required, rifampicin $\left(100 \mu \mathrm{g} \mathrm{ml} \mathrm{l}^{-1}\right)$ was added to trap open complexes $7 \mathrm{~min}$ before addition of $\mathrm{KMnO}_{4}$. Plasmid purification, cleavage with piperidine and extension was as above.
Autoradiograms were analysed densitometrically in a Molecular Dynamics PSI Densitometer and differences in the level of band reactivity were calculated as described by Moret $\&$ Buck (1988).

\section{RESULTS}

\section{Construction of nifA mutants of $\boldsymbol{H}$. seropedicae}

Plasmid pEMS109.1 was used to produce the mutant strain SmR54 that carries a kanamycin-resistance cassette inserted into the coding region of the nif $A$ gene corresponding to the central domain of the NifA protein. This strain failed to reduce acetylene and was complemented by the plasmids pEMS107 (which expresses $H$. seropedicae nifA from the nifA promoter) and pEMS135 (which expresses nifA constitutively from the lac promoter). pEMS109 was used to insert Tn5-B21 in the $H$. seropedicae nifA gene, producing strain SmR2532 carrying the lac $Z$ gene in the same orientation as the nifA gene. This strain was also $\mathrm{Nif}^{-}$and was complemented by plasmid pEMS101, which carries the nifA gene from $H$. seropedicae.

\section{Expression of the $H$. seropedicae nifA gene in $E$. coli}

The nif $A$ : : lacZ fusion in plasmid pEMS120 carrying the whole promoter region of the nifA gene of $H$. seropedicae in the low-copy-number vector pPW452 exhibited a very low expression rate in E. coli ET8894, which increased 50-fold when the NifA protein from $K$. pneumoniae was provided by the plasmid pMC71A (Table 2). Deletion of the NifA UAS (pEMS121) reduced the activity of the nifA promoter by $90 \%$ in the presence of $K$. pneumoniae NifA. Deletion of DNA sequences upstream from base 453 (pEMS122) resulted in a twofold increase in the NifA-dependent $\beta$-galactosidase activity. The NtrC protein of K. pneumoniae expressed from pMM14 also activated expression of the nifA gene (pEMS120). This activation was reduced (65\%) when the NtrC binding site was completely (pEMS122) or partially (pEMS124) deleted.

When a nifA: lacZ fusion was cloned into a mediumcopy-number vector (pBR322) however, the effect of the NtrC binding site was clearer: deletion of the NtrC UAS in pEMS114 reduced activity fivefold compared to that of pEMS111 (Table 2). In E. coli ET8045 (rpoN $\left.{ }^{-}\right)$neither NifA nor NtrC activated the nifA fusion carried by pEMS109 whereas in ET8894 $\left(\operatorname{rpoN}^{+}\right)$a 10-fold or 20fold increase in $\beta$-galactosidase activity was observed when NifA or NtrC, respectively, was expressed constitutively (Table 2). This result indicates that the nifA promoter is dependent on the presence of the rpoN gene product. Addition of $\mathrm{NH}_{4} \mathrm{Cl}(20 \mathrm{mM})$ did not alter nifA expression in E. coli (not shown).

\section{Expression of the nifA gene in $H$. seropedicae}

Expression of the chromosomal nifA gene in $\boldsymbol{H}$. seropedicae nifA::lacZ. Fixed nitrogen $\left(20 \mathrm{mM} \mathrm{NH}_{4} \mathrm{Cl}\right)$ decreased the expression of the $H$. seropedicae chromosomal 
Table 2. $\beta$-Galactosidase activity of nifA:: lacZ fusions in $E$. coli

Data are the means of three independent assays. Numbers in parentheses are standard deviations. ND, Not determined. E. coli strains ET8894 and ET8045 are $n t r C$ and $r p o N$ mutants, respectively. The plasmids are described in the text and in Table 1, and were constructed as described in Methods. Plasmids pEMS120, pEMS111 and pEMS109 contain the whole promoter region of the nifA gene of $H$. seropedicae. Plasmid pEMS114 is a derivative of pEMS111 and contains the same region of the promoter as plasmid pEMS122.

\begin{tabular}{|llccc|}
\hline Strain & $\begin{array}{c}\text { lac } \boldsymbol{Z} \text { fusion } \\
\text { plasmid }\end{array}$ & \multicolumn{3}{c|}{$\begin{array}{c}\beta \text {-Galactosidase activity with } \\
\text { additional plasmid (Miller units) }\end{array}$} \\
\cline { 3 - 5 } & & None & pMC71A & pMM14 \\
\hline ET8894 & pEMS111 & $20(3)$ & ND & $381(83)$ \\
ET8894 & pEMS114 & $34(9)$ & ND & $84(14)$ \\
ET8894 & pEMS120 & $2 \cdot 9(2 \cdot 9)$ & $138(4 \cdot 7)$ & $66(6 \cdot 4)$ \\
ET8894 & pEMS121 & $5 \cdot 0(1 \cdot 6)$ & $16 \cdot 7(7 \cdot 8)$ & ND \\
ET8894 & pEMS122 & $2 \cdot 3(2 \cdot 5)$ & $315(74 \cdot 8)$ & $24 \cdot 5(11 \cdot 7)$ \\
ET8894 & pEMS124 & $5 \cdot 1(2 \cdot 3)$ & $106(7 \cdot 1)$ & $23 \cdot 5(3 \cdot 7)$ \\
& & & & \\
& & & $1471(123)$ & $771(10)$ \\
& & $75(26)$ & $132(107)$ & $77(10)$ \\
\hline ET8894 & pEMS109 & $143(95)$ & & pMM14 \\
ET8045 & pEMS109 & & & \\
\hline
\end{tabular}

Table 3. $\beta$-Galactosidase activity of nifA:: lacZ fusions in $H$. seropedicae

Data are the mean of three independent assays. Numbers in parentheses are standard deviations. The $\beta$-galactosidase activity of $H$. seropedicae strains without any fusion (SmR1 and SmR54) was less than 5 Miller units. The plasmids are described in the text and in Table 1 and were constructed as described in Methods. H. seropedicae SmR1 and SmR54 strains are wild-type and a nifA mutant, respectively. H. seropedicae SmR2532 carries a chromosomal nifA: : lacZ fusion.

\begin{tabular}{|c|c|c|c|c|c|}
\hline \multirow[t]{2}{*}{ Strain } & \multirow{2}{*}{$\begin{array}{c}\text { lac } Z \text { fusion } \\
\text { plasmid }\end{array}$} & \multicolumn{4}{|c|}{$\beta$-Galactosidase activity (Miller units) } \\
\hline & & $-\mathrm{NH}_{4}^{+} / 1 \cdot 5 \% \mathrm{O}_{2}$ & $+\mathrm{NH}_{4}^{+} / 1 \cdot 5 \% \mathrm{O}_{2}$ & $-\mathrm{NH}_{4}^{+} /$air & $+\mathrm{NH}_{4}^{+} /$air \\
\hline SmR2532 & None & $233(46)$ & $51(17)$ & $260(30)$ & $41(7)$ \\
\hline SmR1 & pEMS120 & $579(78)$ & $100(22)$ & $510(107)$ & $49(16)$ \\
\hline SmR1 & pEMS121 & $93(22)$ & $63(15)$ & $155(16)$ & $56(16)$ \\
\hline SmR1 & pEMS122 & $943(85)$ & $123(27)$ & $202(36)$ & $66(10)$ \\
\hline SmR1 & pEMS123 & $440(36)$ & $116(66)$ & $113(45)$ & $57(26)$ \\
\hline SmR1 & pEMS124 & $317(85)$ & $204(78)$ & $209(39)$ & $85(10)$ \\
\hline SmR1 & pEMS125 & $10 \cdot 2(5)$ & $22(9)$ & $17(7)$ & $17(10)$ \\
\hline SmR1 & pEMS126 & $36(17)$ & $66(13)$ & $32(9)$ & $38(10)$ \\
\hline SmR1 & pEMS127 & $129(59)$ & $235(10)$ & $139(83)$ & $184(50)$ \\
\hline SmR54 & pEMS120 & 418 (19) & $75(22)$ & $492(78)$ & $29(3)$ \\
\hline SmR54 & pEMS122 & $148(25)$ & $127(59)$ & $191(86)$ & $50(9)$ \\
\hline SmR54 & pEMS123 & $178(44)$ & $107(28)$ & $207(24)$ & $64(23)$ \\
\hline SmR54 & pEMS124 & $151(3)$ & $126(9)$ & $196(35)$ & $79(5)$ \\
\hline
\end{tabular}

nif A : lacZ fusion (strain SmR2532) by $80 \%$, but oxygen did not repress expression (Table 3).

Expression of plasmid-borne nifA:: lacZ fusions in $H$. seropedicae. As in the chromosomal mutant, the $\beta$ galactosidase expression of the fusion carried by plasmid
pEMS120 (comprising the whole promoter region of the nifA gene) in $H$. seropedicae strain SmR1 was also depressed 4-5-fold in the presence of $20 \mathrm{mM} \mathrm{NH}_{4} \mathrm{Cl}$ but was not substantially affected by oxygen (Table 3 ). Similar levels of expression were observed in strain SmR54 (nifA mutant) carrying pEMS120. Deletion of 
the sequence upstream from base 264 (pEMS124), including half of the $\mathrm{NtrC}$ binding site, decreased the $\beta$ galactosidase activity in SmR1 under normal $\mathrm{N}_{2}$-fixing conditions by $50 \%$; this activity was only depressed $30 \%$ by ammonia. In strain SmR54, expression from this mutant promoter was lower under $\mathrm{N}_{2}$-fixing conditions than in the wild-type (SmR1) with the same deletion and it was insensitive to either added ammonium or air but was depressed further by $50 \%$ when both were added together. Deletion of $179 \mathrm{bp}$ (pEMS123) and $190 \mathrm{bp}$ (pEMS122) from base 264 caused an increase in $\beta$-galactosidase activity under derepressing conditions and marked repression by either ammonium ions or oxygen in the wild-type strain, while in the nifA mutant there was no response to the absence of fixed nitrogen and low oxygen. The $\beta$-galactosidase activity of pEMS122 was twice that of pEMS123 in the derepressing wild-type strain.

Finally, elimination of a region upstream from position 604 (pEMS121), leaving only the $-24 /-12$ promoter sequence, produced a fusion with a low level of expression not regulated by either ammonium ions or oxygen (Table 3). Clearly, the upstream sequences are important for promoter activity.

A set of progressive deletions from the $3^{\prime}$ end of the nifA promoter was also tested. Deleting the $-24 /-12$ promoter (pEMS125) caused a large decrease of $\beta$ galactosidase activity under all conditions. With pEMS126, where both the NifA UAS and the promoter region were eliminated, there was a weak non-regulated expression. That level was increased 3-4-fold in pEMS127, where a further $220 \mathrm{bp}$ were deleted (Table $3)$.

\section{Mapping of the $5^{\prime}$ end of nifA RNA}

To identify the $5^{\prime}$ end of the nifA RNA, a singlestranded probe was synthesized by unidirectional PCR using an oligonucleotide primer labelled with ${ }^{32} \mathrm{P}$. This probe was used for S1 mapping, revealing position 641 as the nifA RNA $5^{\prime}$ end (Fig. 2). No signal was detected with RNA isolated from cultures under repressing conditions (20 $\mathrm{mM} \mathrm{NH}_{4} \mathrm{Cl}$; not shown).

\section{In vivo footprinting}

In vivo footprinting in E. coli. To determine if NifA could bind to the NifA UAS (position 504 to 519) in the promoter region of the $H$. seropedicae nif $A$, the plasmids pEMS111 (carrying the nifA promoter) and pNH11 (expressing K. pneumoniae nif $A$ from the tac promoter) were transformed into E. coli and the culture treated with DMS. In this experiment, the binding of the protein to the DNA is assessed by a relative decrease in methylation (protection) of the G residues and/or by an enhancement of methylation if the base is more exposed to the chemical modification upon protein binding. The $G$ residue of the TGT motif at positions 505 and 518 of the top and bottom strands, respectively, were strongly

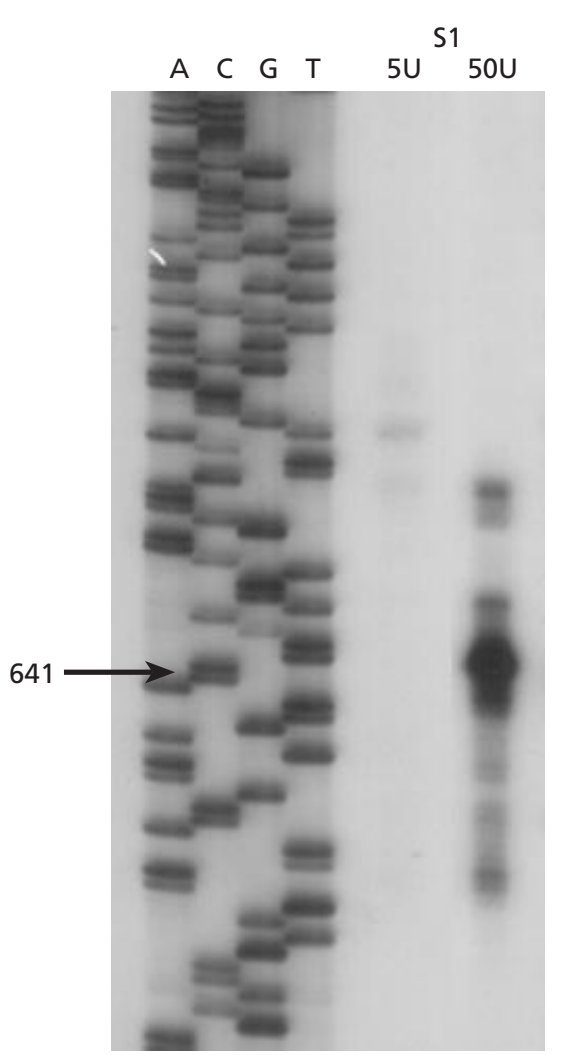

Fig. 2. Mapping of the transcriptional-start site of the nifA gene of $H$. seropedicae. The lanes labelled $5 \mathrm{U}$ and $50 \mathrm{U}$ show the S1 nuclease digestion products with 5 and 50 units of S1 nuclease, respectively, from the hybridization reaction between total RNA and the single-stranded probe synthesized using primer 1 (Methods). The arrow indicates the transcription-start site.

protected in the presence of $K$. pneumoniae NifA (Fig. $3 \mathrm{a}, \mathrm{b}$, lanes 4 and 5), indicating NifA binding to the UAS in vivo. The residues at positions 522 and 525 of the top strand and 527 of the bottom strand were weakly protected by K. pneumoniae NifA. These residues are outside of the NifA UAS but the sequence 522GACGACA may constitute a half NifA UAS.

In vivo footprinting in $\boldsymbol{H}$. seropedicae. To identify the interaction of the $-24 /-12$ promoter sequence with the $\sigma^{\mathrm{N}}$-containing RNA polymerase, cultures of $H$. seropedicae harbouring pEMS120 in the absence or presence of $\mathrm{NH}_{4} \mathrm{Cl}$ with and without rifampicin, were chemically treated with DMS or permanganate. In the DMS footprinting, methylation of the residue at position $615(-26)$ of the top strand was enhanced in the absence of fixed nitrogen and that of residue $632(-9)$ when rifampicin was also added (Figs 4 and 5). In the bottom strand there was no substantial difference between the four conditions (not shown). Enhancement of methylation of residue -26 might reflect a higher occupancy of the promoter by $\sigma^{\mathrm{N}}$-containing RNA polymerase under nitrogen-fixing conditions, whereas the altered reactivity of residue -9 might be due to formation of an open 
(a)

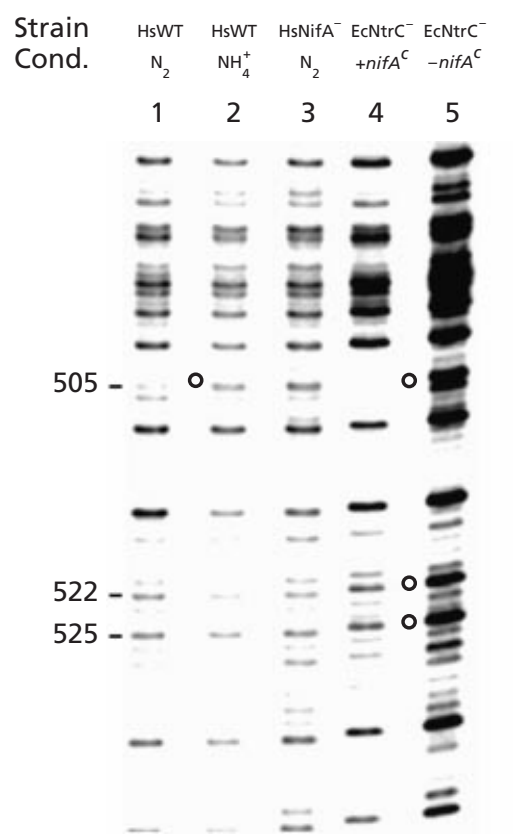

(b)

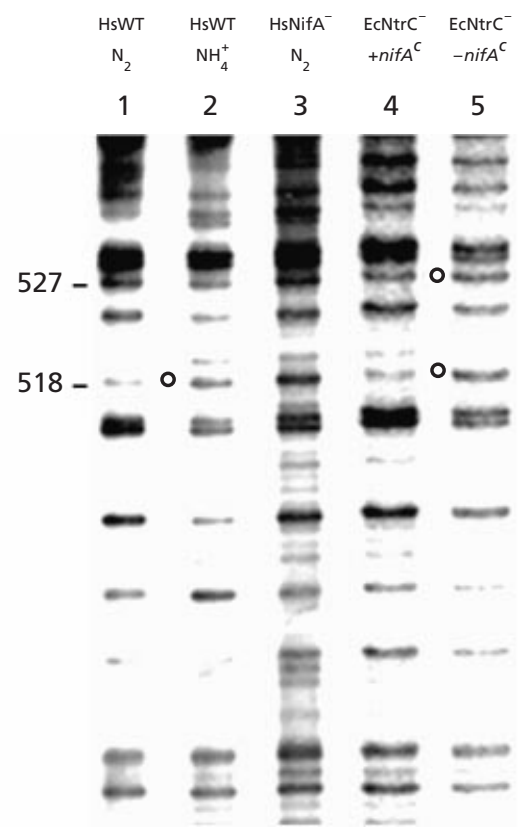

Fig. 3. Interaction of NifA UAS of $H$. seropedicae nifA promoter with the NifA protein. Bands protected from methylation by DMS in the presence of NifA expressed constitutively in $E$. coli or under nitrogen-fixing conditions in $H$. seropedicae are indicated by $\bigcirc$. (a) Top strand. (b) Bottom strand. Lanes: 1, SmR1(pEMS120) under nitrogen-fixing conditions; 2 ,

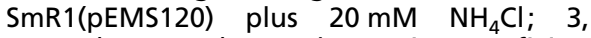
SmR54(pEMS120) under nitrogen-fixing conditions; 4, ET8894(pEMS111) with $K$. pneumoniae NifA provided by pNH11; 5, ET8894(pEMS111).

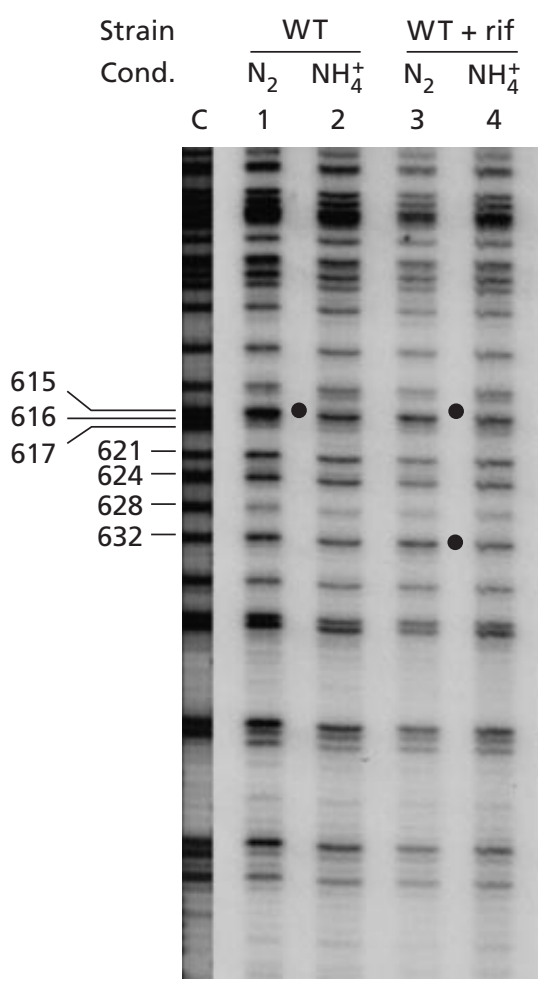

Fig. 4. DMS footprinting of the top strand of the $-24 /-12$ element of $H$. seropedicae nifA. Hypermethylation is indicated by 0 . Lanes: 1, SmR1(pEMS120) under nitrogen-fixing

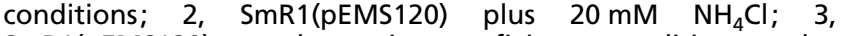
SmR1(pEMS120) under nitrogen-fixing conditions plus rifampicin; 4, SmR1(pEMS120) plus $20 \mathrm{mM} \mathrm{NH} \mathrm{NH}_{4} \mathrm{Cl}$ and rifampicin. Rifampicin was added to block RNA synthesis and trap the nifA promoter in the open-complex form. For comparison, the $C$ sequencing track (corresponding to the $G$ position of the top strand) is shown. No obvious protection was detected. complex. DMS footprinting of the promoter region of the nifA in an E. coli rpoN ${ }^{+}$(ET8894) strain revealed that the $G$ residue at position $616(-25)$ in the top strand was protected in the presence of the rpoN gene (not shown), also suggesting interaction of the $\sigma^{\mathrm{N}_{-}}$ containing RNA polymerase with this sequence. In the bottom strand no protection was observed.

Permanganate footprinting probes for open-complex formation, since $\mathrm{T}$ residues of single-stranded DNA become more reactive. The $\mathrm{T}$ residue at position 650 $(+10)$ in the top strand was slightly more reactive towards permanganate in the absence of ammonium ions than in their presence (Fig. 6a, lanes 3 and 4; Fig. 7). When rifampicin was added to trap open complexes, $\mathrm{T}$ residues at positions $631,643,647,649$ and $650(-10$, $+3,+7,+9$ and +10$)$ were more reactive in the absence than in the presence of fixed nitrogen (Fig. 6a, lanes 1 and 2; Fig. 7). These results suggest melting of the region between residues -10 and +10 during opencomplex formation under nitrogen-fixing conditions. The only residue in the bottom strand to show an increased reactivity towards permanganate was T 633 (position -8) in the presence of rifampicin (Fig. 6b). Permanganate footprinting of the nifA promoter was determined in ET8894 $\left(r p o N^{+}\right)$and ET8045 $\left(r p o N^{-}\right)$ carrying pEMS109 (HsnifA promoter) and pCK1 (K. pneumoniae nif $A^{\mathrm{c}}$ ) in the presence of rifampicin. In the $r p o N^{+}$strain, the residues at positions 631, 643 and 647 in the top strand $\left(-10,+3\right.$ and +7 in relation to the $5^{\prime}$ end of nifA RNA) showed an increase in reactivity towards $\mathrm{KMnO}_{4}$ (not shown). No increase in reactivity was identified in the bottom strand.

To determine whether there was a change in methylation by DMS in the NifA UAS (positions 504-519), plasmid DNA was purified from H. seropedicae strain SmR1 

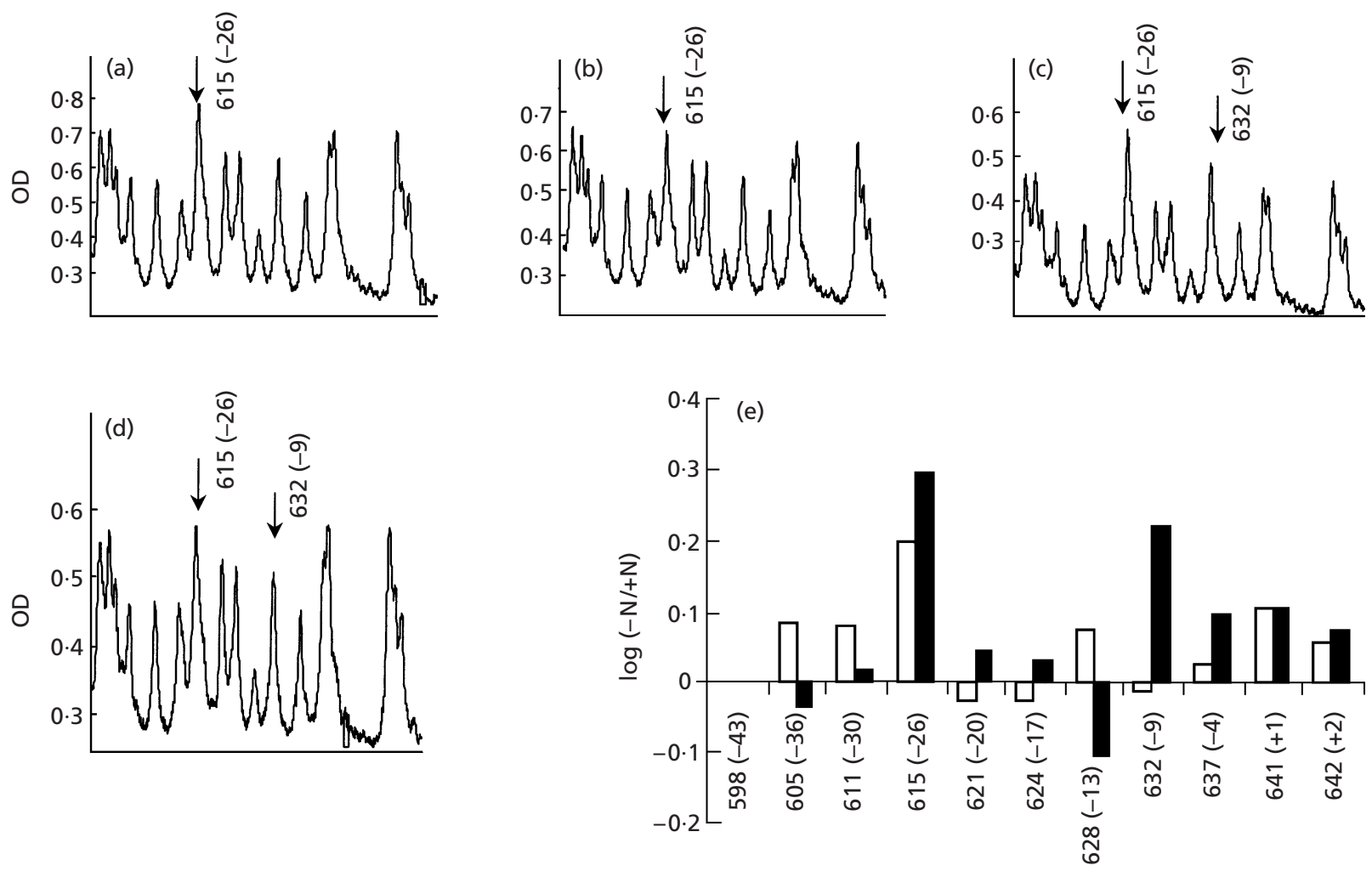

Residue

Fig. 5. Densitometric analysis of the DMS footprint at top strand of the $H$. seropedicae nifA promoter. (a) SmR1(pEMS120) under nitrogen-fixing conditions. (b) SmR1(pEMS120) plus $20 \mathrm{mM} \mathrm{NH}_{4} \mathrm{Cl}$. (c) SmR1(pEMS120) under nitrogen-fixing conditions plus rifampicin. (d) SmR1(pEMS120) plus $20 \mathrm{mM} \mathrm{NH}_{4} \mathrm{Cl}$ and rifampicin. (e) The autoradiographs were scanned and the peak heights determined. The normalized height of each peak under nitrogen-fixing conditions was divided by the value in the presence $20 \mathrm{mM} \mathrm{NH}_{4} \mathrm{Cl}$ and expressed as the logarithm of the quotient. Peaks were normalized against the value of residues 598. Rifampicin was added (black bars) or not (white bars) to trap open complexes. Positive values indicate hypermethylation and negative values indicate protection. Guanine residue -26 is hyper-reactive under derepressing conditions while residue -9 is hypermethylated only when rifampicin was added to derepressed cells.

(pEMS120) derepressed in either the absence or presence of $20 \mathrm{mM} \mathrm{NH}_{4} \mathrm{Cl}$ and from H. seropedicae strain SmR54 (pEMS120) derepressed in the absence of fixed nitrogen. The $\mathrm{G}$ residue at position 505 of the top strand and the residue 518 of the bottom strand were protected from methylation by DMS in the absence of $\mathrm{NH}_{4} \mathrm{Cl}$, indicating binding of the NifA protein under nitrogen-fixing conditions (Fig. 3a, b, compare lane 1 with lanes 2 and $3)$.

\section{DISCUSSION}

The results of the expression of the nif $A$ gene of $H$. seropedicae in an enteric background (Table 2) indicated that the transcription of this gene was activated by either the NifA or NtrC proteins and is dependent on the $\sigma^{\mathrm{N}}$ factor. Indeed, the nifA RNA $5^{\prime}$ end was mapped under derepressing conditions at position 641 and, $11 \mathrm{bp}$ upstream from this position, a sequence homologous to a $-24 /-12$ promoter element (nif Ap) is located (Fig. 1a). The relatively high activity of the fusion with the
NtrC UAS deleted may be due to interaction between non-bound $\mathrm{NtrC}$ and the closed promoter $/ \sigma^{\mathrm{N}}$-containing RNA polymerase complex.

The expression of nifA in $H$. seropedicae is regulated by fixed nitrogen (4-5-fold reduction by $\mathrm{NH}_{4} \mathrm{Cl}$ ) but not by oxygen (Table 3). The expression levels of nif $A$ in the $H$. seropedicae nif A mutant carrying pEMS120 were similar to those in the wild-type carrying the same plasmid, which suggests that, contrary to results in E. coli, the NifA protein is not essential for the expression of the nifA gene in $H$. seropedicae. Partial deletion of the $\mathrm{NtrC}$ UAS (pEMS124) abolished the regulation by ammonium ions but decreased by half the $\beta$-galactosidase activity in the wild-type carrying pEMS120, indicating that the putative NtrC UAS is necessary for activation of nifA gene expression in $H$. seropedicae. These results, together with transcription-start-site mapping, indicate that the increase in nifA expression under nitrogenfixing conditions is primarily dependent on the $\mathrm{NtrC}$ activation of the $-24 /-12$ promoter element. 
(a) Strain $\mathrm{WT}+$ rif $\mathrm{WT}$

Cond. $\overline{\mathrm{N}_{2}} \mathrm{NH}_{4}^{+} \overline{\mathrm{N}_{2}} \mathrm{NH}_{4}^{+}$

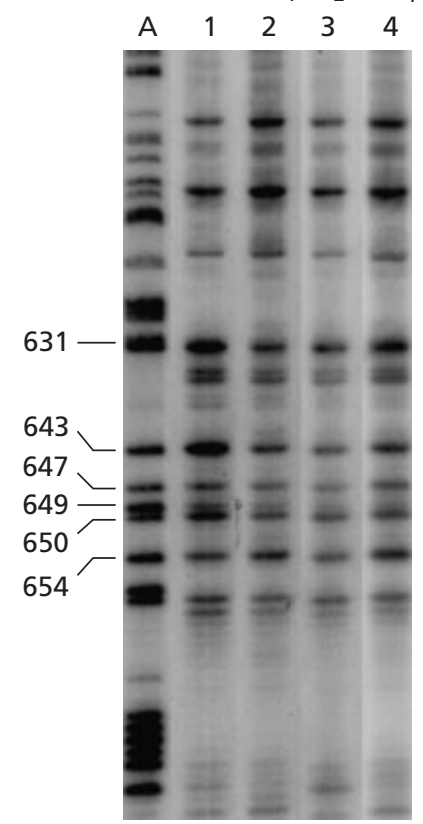

(b) Strain $\mathrm{WT} W T+$ rif

Cond. $\overline{\mathrm{N}_{2} \mathrm{NH}_{4}^{+}} \overline{\mathrm{N}_{2} \mathrm{NH}_{4}^{+}}$

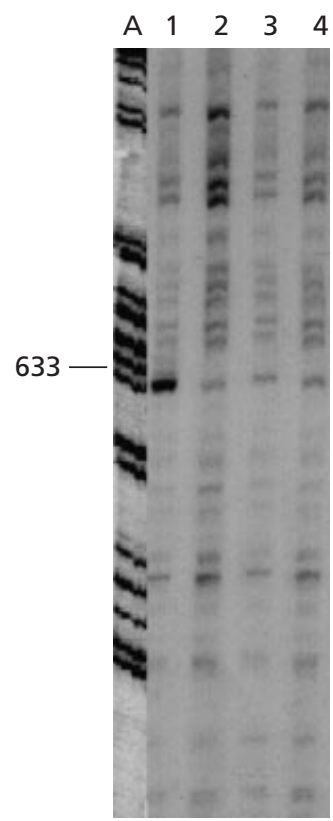

Fig. 6. Probing open complexes at the $H$. seropedicae nifA promoter with $\mathrm{KMnO}_{4}$. (a) Top strand. (b) Bottom strand. Lanes: 1, SmR1(pEMS120) under nitrogen-fixing conditions plus rifampicin; 2, SmR1(pEMS120) plus $20 \mathrm{mM} \mathrm{NH} \mathrm{NH}_{4} \mathrm{Cl}$ and rifampicin; 3, SmR1(pEMS120) under nitrogen-fixing conditions; 4, SmR1(pEMS120) plus $20 \mathrm{mM}$ $\mathrm{NH}_{4} \mathrm{Cl}$. Rifampicin was added to block RNA synthesis and trap the nifA promoter in the open complex form. For comparison, the A sequencing track (corresponding to the $T$ positions) is shown.
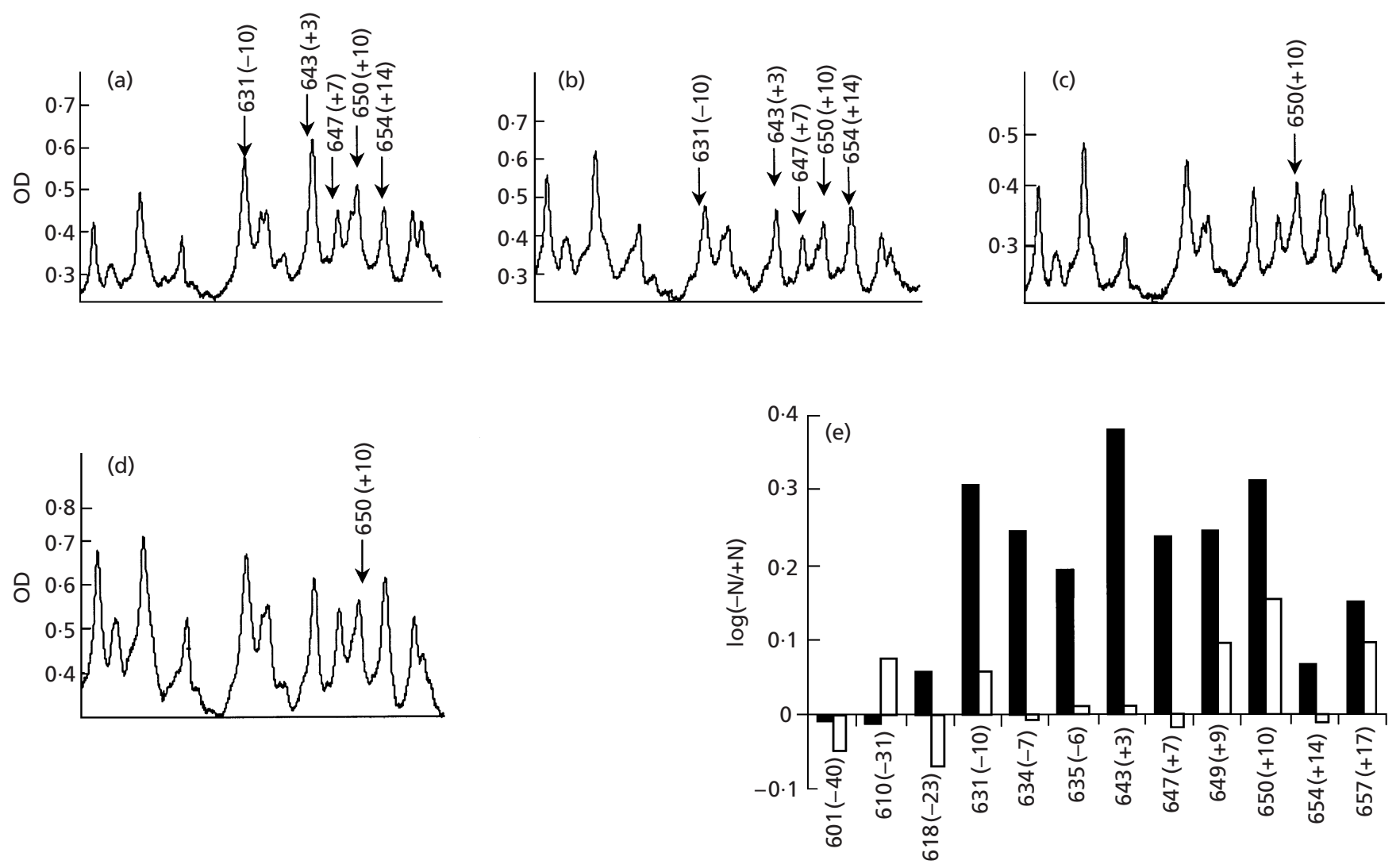

Fig. 7. Densitometric analysis of potassium permanganate footprinting of the top strand at the $H$. seropedicae nifA promoter. (a) SmR1(pEMS120) under nitrogen-fixing conditions plus rifampicin. (b) SmR1(pEMS120) plus $20 \mathrm{mM} \mathrm{NH}_{4} \mathrm{Cl}$ and rifampicin. (c) SmR1(pEMS120) under nitrogen-fixing conditions. (d) SmR1(pEMS120) plus $20 \mathrm{mM} \mathrm{NH}_{4} \mathrm{Cl}$. (e) The autoradiographs were scanned and the peak heights determined. The normalized height of each peak under nitrogenfixing conditions was divided by the value in the presence of $20 \mathrm{mM} \mathrm{NH} \mathrm{Nl}_{4} \mathrm{Cl}$ and expressed as the logarithm of the quotient. Peaks were normalized against the value of residues 610. Rifampicin was added (black bars) or not (white bars) to trap open complexes. Positive values indicate hyper-reactivity towards permanganate. 
Regulation by ammonium or oxygen, as well as dependence upon the NifA protein, was introduced when all but 70 bp upstream of the putative NifA binding site (pEMS123, Fig. 1b) was deleted. Elimination of a further $20 \mathrm{bp}$ (pEMS122) had the same pattern, although the $\beta$ galactosidase activity under nitrogen-fixing conditions was higher in the wild-type strain carrying pEMS122 than that carrying pEMS123 (Table 3). Interestingly, the fusion carried by pEMS122 expressed $\beta$-galactosidase at twice the level of that of pEMS120, suggesting that the sequences upstream from the NifA binding site interfere with the ability of NifA to activate this promoter.

Although NifA is not essential for nifA expression (579 Miller units in the wild-type compared to 418 in the $\mathrm{NifA}^{-}$background), it may contribute to the full expression at the promoter. Moreover, the $\beta$-galactosidase activities with the deletions in plasmids pEMS123 and pEMS122 indicate that the NifA UAS is functional under certain conditions in H. seropedicae. This conclusion is also supported by footprinting evidence showing that NifA does interact with its putative UAS. DMS footprinting in E. coli showed that the G residues of TGT motifs in both top and bottom strands were strongly protected by NifA (Fig. 3a, b); two positions in the NifA UAS of $K$. pneumoniae nif genes that are characteristically protected by bound NifA (Morett $\&$ Buck, 1988). The half NifA UAS located at position 522-528 was also protected, possibly due to the high concentration of the NifA protein produced by pNH11 allowing for the binding to a lower-affinity DNA sequence. In $H$. seropedicae the G residues of the TGT motif of the NifA UAS were protected in both strands in the absence of fixed nitrogen. Since nif $A$ expression is activated under this condition, this result suggests that the NifA protein is able to bind to the NifA UAS in $H$. seropedicae. Plasmids pEMS122 and pEMS123, which lack the sequences at the $5^{\prime}$ end of the NifA UAS, show higher activation dependent on NifA. It is possible that the sequences close to the $5^{\prime}$ end of the NifA UAS play a regulatory role in NifA activation of the $-24 /-12$ promoter. The sequence $\sim 50 \mathrm{bp}$ upstream from the NifA UAS may constitute an IHF binding site (Souza et al., 1991a). Presumably the IHF could inhibit NifA binding and hence transcription in the absence of a NtrC UAS. This possibility parallels the observation by Austin et al. (1994) that NifA-dependent in vitro transcription of the nifH promoter was inhibited by the IHF if the NifA UAS was deleted. IHF and NifA may compete for binding in this DNA region and regulate nifA expression by a feedback mechanism. Only when the NifA concentration is high enough can it out-compete the IHF and activate the $-24 /-12$ promoter. Alternatively, a high concentration of NifA might activate the promoter with binding to the UAS.

DMS footprinting of the putative $-24 /-12$ promoter of the nifA gene confirmed that this region was in contact with the $\sigma^{\mathrm{N}}$-containing RNA polymerase. The $-25 \mathrm{G}$ residue (in relation to the RNA $5^{\prime}$ end) alone was protected in the top strand but no base was protected in the bottom strand in E. coli (not shown) indicating weak contact, since the residues $-25,-24$ and -12 are characteristically protected by $\sigma^{\mathrm{N}}$-containing RNA polymerase in E. coli (Buck \& Cannon, 1989). In $H$. seropedicae, when the promoter was trapped in the open-complex form by the addition of rifampicin, residues -26 and -9 were hypermethylated under nitrogen-fixing conditions, suggesting contact with the $\sigma^{\mathrm{N}}$-containing RNA polymerase. Hypermethylation of residue -9 by DMS also occurs in the open complex of the nifU promoter of $K$. pneumoniae (Buck \& Cannon, 1992). Finally, the permanganate footprinting (Fig. 6) showed that the region between -10 and +10 of the $H$. seropedicae nifA promoter was more reactive towards permanganate, and probably engaged in an open complex under nitrogen-fixing conditions. These results indicated that the identified $-24 /-12$ promoter sequence of $H$. seropedicae nifA is transcriptionally active in the absence of fixed nitrogen.

In pEMS127, where the $-24 /-12$ promoter, the NifA and $\mathrm{NtrC}$ UASs were deleted, nifA expression was low and not regulated by ammonium ions or oxygen, neither in E. coli nor in $H$. seropedicae. In addition, a background level of nifA expression was present under repressing conditions, suggesting the presence of an upstream promoter. This promoter organization could maintain a constitutive low level of nif A RNA synthesis, allowing a low level of NifA protein to activate the expression of nif genes as soon as conditions become favourable for nitrogen fixation. On the other hand, smaller deletions of the $3^{\prime}$ region, which leave the NtrC and NifA binding sites present, decreased the level of expression from this putative promoter in pEMS125 and pEMS126 in H. seropedicae. In E. coli pEMS125 also had a very low level of expression. It is possible that the region between bases 264 and 442 may destabilize the RNA or that binding of regulatory proteins diminishes transcription.

The nif $A$ promoter active under nitrogen-fixing conditions is of the type $-24 /-12$. This promoter is transcriptionally active in both E. coli and H. seropedicae. In H. seropedicae this promoter is repressed by fixed nitrogen but not by oxygen and is probably activated by the NtrC protein. NifA is apparently not essential for nifA expression but it can still bind the NifA UAS and may activate transcription when present in sufficient amounts to out-compete the IHF.

\section{ACKNOWLEDGEMENTS}

We thank Martin Buck for discussion and suggestions, and Rose A. Monteiro and Fabiane M. Rego for assistance with the densitometric analysis. We also thank CNPq and FINEP/ MCT/Pronex for financial support.

\section{REFERENCES}

Arsene, F., Kaminski, P. A. \& Elmerich, C. (1996). Modulation of NifA activity by PII in Azospirillum brasilense: evidence for a regulatory role of the NifA N-terminal domain. J Bacteriol 178, $4830-4838$. 
Austin, S., Henderson, N. \& Dixon, R. (1990). Characterization of the Klebsiella pneumoniae nitrogen-fixation regulatory protein NifA and NifL 'in vitro'. Eur J Biochem 187, 353-360.

Austin, S., Buck, M., Cannon, W., Eydmann, T. \& Dixon, R. (1994). Purification and in vitro activities of the native nitrogen fixation control proteins NifA and NifL. J Bacteriol 176, 3460-3465.

Baldani, J. I., Baldani, V. L. D., Seldin, L. \& Dobereiner, J. (1986). Characterization of Herbaspirillum seropedicae gen. nov., sp. nov., a root-associated nitrogen-fixing bacterium. Int $J$ Syst Bacteriol 36, 86-93.

Batut, J., Daveran-Mingot, M.-L., David, M., Jacob, J., Garnerone, A. M. \& Kahn, D. (1989). fixK, a gene homologous with $f n r$ and $c r p$ from Escherichia coli, regulates nitrogen fixation genes both positively and negatively in Rhizobium meliloti. EMBO $J \mathbf{8}$, 1279-1286.

Bauer, E., Kaspar, T., Fischer, H.-M. \& Hennecke, H. (1998). Expression of the fixR-nifA operon in Bradyrhizobium japonicum depends on a new response regulator, RegR. J Bacteriol 180, 3853-3863.

Benelli, E. M., Souza, E. M., Funayama, S., Rigo, L. \& Pedrosa, F. O. (1997). Evidence for two possible glnB-type genes in Herbaspirillum seropedicae. J Bacteriol 179, 4623-4626.

Boddey, R. M., Oliveira, O. C., Urquiaga, S., Reis, V. M., Olivares, F. L., Baldani, V. L. D. \& Döbereiner, J. (1995). Biological nitrogen fixation associated with sugar cane and rice: contributions and prospects for improvement. Plant Soil 174, 195-209.

Buchanan-Wollaston, V., Cannon, M. C., Beynon, J. C. \& Cannon, F. C. (1981). Role of the nif $A$ gene product in the regulation of nif expression in Klebsiella pneumoniae. Nature 294, 776-778.

Buck, M. \& Cannon, W. (1989). Mutations in the RNA polymerase recognition sequence of the Klebsiella pneumoniae nifH promoter permitting transcriptional activation in the absence of NifA binding to upstream activator sequences. Nucleic Acids Res 7, 2597-2612.

Buck, M. \& Cannon, W. (1992). Activator-independent formation of a closed complex between $\sigma^{54}$-holoenzyme and nifH and nifU of Klebsiella pneumoniae. Mol Microbiol 6, 1625-1630.

David, M., Daveran, M. L., Batut, J., Dedieu, A., Domergue, O., Gai, J., Hertig, C., Boistard, P. \& Kahn, D. (1988). Cascade regulation of nif gene expression in Rhizobium meliloti. Cell 54, 671-683.

Dixon, R. (1988). Genetic regulation of nitrogen fixation. In The Nitrogen and Sulphur Cycles. (Society for General Microbiology symposium no. 42), pp. 417-438. Edited by J. A. Cole \& S. J. Ferguson. Cambridge: Cambridge University Press.

Dixon, R., Kennedy, C., Kondorosi, A., Krishnapillai, V. \& Merrick, M. (1977). Complementation analysis of Klebsiella pneumoniae mutants defective in nitrogen fixation. Mol Gen Genet 157, 189-198.

Figurski, D. H. \& Helinski, D. R. (1979). Replication of an origincontaining derivative of plasmid RK2 dependent on a plasmid function provided in trans. Proc Natl Acad Sci U $S$ A 76, 1648-1652.

Fischer, H.-M. \& Hennecke, H. (1987). Direct response of Bradyrhizobium japonicum nifA-mediated nif gene regulation to cellular oxygen status. Mol Gen Genet 209, 621-626.

Kaminski, P. A. \& Elmerich, C. (1998). The control of Azorhizobium caulinodans nifA expression by oxygen, ammonia and by the HF-I-like protein, NrfA. Mol Microbiol 28, 603-613.

Kennedy, C. \& Robson, R. L. (1983). Activation of nif gene expression in Azotobacter by the nifA gene product of Klebsiella pneumoniae. Nature 301, 626-628.
Knauf, V. C. \& Nester, E. W. (1982). Wide host range cloning vectors: a cosmid bank of an Agrobacterium Ti plasmid. Plasmid $8,45-54$.

Krol, A. J. M., Hontelez, J. G. J., Roozendaal, B. \& Kammen, A. (1982). On the operon structure of the nitrogenase of Rhizobium leguminosarum and Azotobacter vinelandii. Nucleic Acids Res 10, 4147-4157.

Liang, Y. Y., Kaminski, P. A. \& Elmerich, C. (1991). Identification of a nifA-like regulator gene of Azospirillum brasilense Sp7 expressed under conditions of nitrogen fixation and in the presence of air and ammonia. Mol Microbiol 5, 2735-2744.

Loroch, A. I., Nguyen, B. G. \& Ludwig, R. A. (1995). Interactive regulation of Azorhizobium nifA transcription via overlapping promoters. J Bacteriol 177, 7210-7221.

MacNeil, D. (1981). General method, using Mu-Mud1 dilysogens, to determine the direction of transcription of and generate deletions in the $g \ln A$ region of Escherichia coli. J Bacteriol 146, 260-268.

Merrick, M. (1983). Nitrogen control of the nif regulon in Klebsiella pneumoniae: involvement of the ntrA gene and analogies between $n t r C$ and nifA. EMBO J 2, 39-44.

Merrick, M. \& Edwards, R. A. (1995). Nitrogen control in bacteria. Microbiol Rev 59, 604-622.

Miller, J. H. (1972). Experiments in Molecular Genetics. Cold Spring Harbor, N Y: Cold Spring Harbor Laboratory.

Moret, E. \& Buck, M. (1988). NifA-dependent in vivo protection demonstrates that the upstream activating sequence of nif promoters is a protein-binding site. Proc Natl Acad Sci U S A 85, 9401-9405.

Moret, E. \& Buck, M. (1989). In vivo studies on the interaction of RNA polymerase- $\sigma^{54}$ with Klebsiella pneumoniae and Rhizobium meliloti nifH promoters: the role of NifA in the formation of an open promoter complex. J Mol Biol 210, 65-77.

Nees, D. W., Stein, P.A. \& Ludwig, R. A. (1988). The Azorhizobium caulinodans nifA gene: identification of upstream activating sequences including a new element, the 'anaerobox'. Nucleic Acids Res 16, 9839-9853.

Pedrosa, F. O. \& Yates, M. G. (1984). Regulation of nitrogen fixation (nif) genes of Azospirillum brasilense by nifA and ntr $(g \ln )$ type gene products. FEMS Microbiol Lett 23, 95-101.

Sambrook, J., Fritsch, E. F. \& Maniatis, T. (1989). Molecular Cloning: a Laboratory Manual, 2nd edn. Cold Spring Harbor, NY: Cold Spring Harbor Laboratory.

Sasse-Dwight, S. \& Gralla, J. D. (1991). Footprinting protein-DNA complexes in vivo. Methods Enzymol 208, 146-168.

Simon, R., Priefer, U. \& Pühler, A. (1983). A broad host range mobilization system for in vivo genetic engineering: transposon mutagenesis in Gram-negative bacteria. Biotechnology 1, 784-791.

Simon, R., Quandt, J. \& Klipp, W. (1989). New derivatives of transposon Tn5 suitable for mobilization of replicons, generation of operon fusions and induction of genes in Gram-negative bacteria. Gene 80, 161-169.

Souza, E. M., Funayama, S., Rigo, L. U., Yates, M. G. \& Pedrosa, F. O. (1991a). Sequence and structural organization of a nifA-like gene and part of a nifB-like gene of Herbaspirillum seropedicae strain Z78. J Gen Microbiol 137, 1511-1522.

Souza, E. M., Funayama, S., Rigo, L. U. \& Pedrosa, F. O. (1991b). Cloning and characterization of the nifA gene from Herbaspirillum seropedicae. Can J Microbiol 37, 425-429.

Souza, E. M., Drummond, M., Pedrosa, F. O., Rigo, L. U. \& Yates, 
M. G. (1999). Control of Herbaspirillum seropedicae NifA activity by ammonium ions and oxygen. J Bacteriol 181, 681-684.

Spaniak, H. P., Okker, R. J. H., Wijffelman, C. A., Pees, E. \& Lugtenberg, B. J. J. (1987). Promoters in the nodulation region of the Rhizobium leguminosarum Sym plasmid pRL1JI. Plant Mol Biol 9, 27-39.

Stigter, J., Schneider, M. \& de Bruijn, F. J. (1992). Azorhizobium caulinodans nitrogen fixation $(n i f / f i x)$ gene regulation: mutagenesis of the nif $A-24 /-12$ promoter element, characterization of a $n t r A(r p o N)$ gene, and derivation of a model. Mol Plant-Microbe Interact 6, 238-252.
Young, J. P. W. (1992). Phylogenetic classification of nitrogenfixing organisms. In Biological Nitrogen Fixation, pp. 43-88. Edited by G. Stacey, R. H. Burris \& H. J. Evans. New York: Chapman \& Hall.

de Zamaroczy, M., Paquelin, A. \& Elmerich, C. (1993). Functional organization of the $g \ln B-g \ln A$ cluster of Azospirillum brasilense. J Bacteriol 175, 2507-2515.

Received 6 July 1999; revised 29 December 1999; accepted 21 March 2000. 